\title{
The Role of Financial Hedging in Preventing Economic Corruption Penetration: A Field Study
}

\author{
Khaled Abdalla Moh'd AL-Tamimi ${ }^{1}$, Samer Fakhri Obeidat ${ }^{2}$, Mohammad Sulieman Jaradat ${ }^{3} \&$ Ashraf \\ Mahammad Al-Rjoub ${ }^{4}$ \\ ${ }^{1}$ Associate Professor in Economics, Department of Administrative and Financial Sciences, Irbid University \\ College, Al-Balqa' Applied University, Jordan \\ ${ }^{2}$ Instructor in Finance and Management, Department of Administrative and Financial Sciences, Irbid University \\ College, Al-Balqa' Applied University, Jordan \\ ${ }^{3}$ Associate Professor in Economics, Department of Banking and Financial Sciences, Ajloun National University, \\ Jordan \\ ${ }^{4}$ Associate Professor in Financial Accounting, Department of Administrative and Financial Sciences, Irbid \\ University College, Al-Balqa' Applied University, Jordan \\ Correspondence: Khaled Abdalla Moh'd AL-Tamimi, Associate Professor in Economics, Department of \\ Administrative and Financial Sciences, Irbid University College, Al-Balqa' Applied University, Jordan. E-mail: \\ khaled_tamimi@yahoo.com
}

Received: April 7, 2019

doi:10.5539/ijef.v11n5p139
Accepted: April 22, $2019 \quad$ Online Published: April 25, 2019

URL: https://doi.org/10.5539/ijef.v11n5p139

\begin{abstract}
The Study aimed at identifying the extent of accounts auditors contribution and their role in financial hedging to prevent economic corruption of public held companies. Results showed a great contribution of accounts auditor in preventing economic corruption in Jordanian publicly held composes. Results also showed a great contribution of internal auditor at Jordanian public held companies in his role in preventing economic corruption in accordance with financial and professional criteria requirements.
\end{abstract}

Keywords: financial hedging, economic corruption, public held company, internal auditor

\section{Introduction}

Corruption and its confrontation, in recent times acquired the interest of countries all over the world as well as that of international committees, governmental and nongovernmental organizations, and this interest stemmed out of its negative reflections on economic activity and society as a wholes, given that corruption is one of the age lesion that is not confined to one culture or country, since it can be found in developing and developed country as well, it is also found in both public and private sectors and at all society classes, however its biggest possible effect is found in developing countries that make its best efforts to improve its economic and social status and defeating their poverty and unemployment problem (Abu-Hmoudh, 2002). Recognizing the negative relationship between corruption various aspects and both economic and social development, Jordan adopted a national strategy which the top proprieties was to fight various aspects of corruption, also in a letter addressed from his Majesty king Abdullah II to prime minister on establishing a committee for the execution of a general strategy to fight corruption which stated we are looking forward to a committee that is in charge of following anyone looking for corruption and spoilage or slipping in its routes, as we are looking to make efforts aiming at drying corruption places, closing its windows, making people aware of its dangerous negative effects on economic, social and political development and on Jordan credibility among international investors and institutions (Royal Letter, 2005). Some international aid agencies in several African countries mentioned the payment of big amounts of money for their government as bribes for the delivery of humanitarian aid for poor people. Also, in a study of the international bank on 3600 companies in 60 countries, the bank considered corruption as the first obstacle facing investment in both Africa and Latin America, while corruption was the second obstacle in Middle east and north Africa, but it was the third in east Asia and previous soviet union countries, while it came faith in industrial countries (Al-Munief, 2015). In short, competition became one of the biggest global problems, which can be considered, by consensus of international of global committees, as the 
major obstacle in front of economic development, where the world bank estimated that more than (800) billion dollars are the annual amount assigned for bribery deals however other studies, conducted in both Thailand and Indonesia, revealed that their government is obliged to pay between $(20-60 \%)$ as an increase in the prices that must be paid, due to corruption, such that it became one of production cost components (Zygler, 2002). Moreover, numerous economic problem that concern economic planners and policy makers, are found in various countries, particularly in developing ones, among these is the economic corruption, of which all developed and developing countries suffer, even although with varied size and effect, depending on political economic, and social combination for each country, therefore economic corruption is among the dangerous phenomena facing nations and developing ones in particular, where they started affecting and damaging their societies, starting with their security and what followed of paralyzed economic building and development process which included destroying their economies financial and administrative capacity. Meanwhile this problem gained the interest of numerous researchers and interested people, also there was a consensus of opinions regarding the need for setting and establishing an institutional framework aiming at surrounding the problem and finding a solution through serious and specific steps as well as fighting the corruption in all its manifests and aspects in all life domains, to accelerate economic development process. Hover, financial scandals and financial fraught claims that occurred in past years, highlighted the weakness of internal control systems and their role in modern business organization (Arena et al., 2006).

\section{Statement of the Problem}

The problem of the current study can be summarized in the need for assessing the extent of development of internal audit function within Jordanian publicly held companies by answering following research question: Does audit function perform its assigned role in preventing economic corruption in publicly held companies?

\section{Research Objectives}

This study aimed at identifying the extent to which internal auditor, at Jordanian publicly held companies, performs his role in preventing economic corruption according to professional traditions and standards.

\section{Significance of the Study}

Significance stems out from the vitality and importance of its topic for project administration shareholders and financial community, as the optimal use of available economic resources, forms a target that efforts must be consolidated for its achievement, and there no doubt that company's internal auditor is charged with an important load in this regard, as from his responsibilities dictated by his profession and what financial community expects from him after great bankruptcy cases which occurred in the USA or South East Asia, which put the audit profession in front of a great challenge in monitoring and evaluating the administration work in front of shareholders.

\section{Significant Previous Studies}

Oleimat (2015) conducted a study entitled "Corruption reflections on economic development" aiming at identifying corruption indicators and the reflections on economic development. Results showed that corruption was related to economic and political stability and is a major embedment of economic development in Jordan.

Omar (2011) conducted study entitled "Corruption and its effect on discrepancy of income distribution and poverty" a comparative study. The study focused on the development of corruption concept in economic thought and practice. He also addressed the study of the relationship between corruption and discrepancy in income distribution and poverty in some countries .

Modalal (2007) conducted a study entitled "Role of internal audit in controlling financial and administrative performance", a field study on publicly held companies registered in Palestinian stock market. The study aiming at highlighting the role of internal audit function in controlling financial and managerial performance in Palestinian publicly held organizations. Result showed that internal units in Palestine do a great work in controlling financial and managerial performance and contribute in the companies governance through their role in evaluating internal control system, supporting risk management as well as measuring its effectiveness and efficiency .

Sarens and Beelde (2006) conducted a study entitled "contemporary internal auditing practices: (new) roles and influencing variables. Evidence of an extended studies". The study aimed at clarifying the role of internal auditors in risks management process, comparing the role of internal auditors, in America and Belgium, in risk management. Results showed that internal auditors in Belgium focus their interest and care on correcting any deficits in their companies risk management systems, playing a crucial role in spreading awareness and realization, formulating a suitable system for risk management. 
Bakri (2005) conducted as study entitled "the role of internal review in activating control in business organizations, the study sought clarifying the role of internal review in the evaluation of internal control system as well as working on its improvement and development. Results showed that financial failure and instability from which numerous companies in America and Malaysia suffered was the result of poor and weak control system, specially, control on risk management.

\section{Research Hypothesis}

$\mathrm{H}_{1}$ : External accounts auditor contributes to the prevention of cases economic corruption in Jordan publicly held companies.

$\mathrm{H}_{2}$ : Financial auditor in Jordanian publicly held companies contributes, through his role, to the prevention of economic corruption according to professional traditions and standards.

$\mathrm{H}_{3}$ : There is a relationship between auditor's qualifications and experience, from one hand and prevention of economic corruption in Jordanian publicly held companies.

\section{Research Methodology}

Population and sample: The study population consists of all publicly held companies in north Jordan governorates for the year 2016-2017, however the study sample consisted of (35) financial managers and auditors, where (35) questionnaires were administered.

\section{Economic Corruption Definition}

Despite the multiplicity of opinions addressing the economic corruption definition, they all agreed that it constituted one of the most important impediment of economic development, due to what it causes of economic waste and disastrous damage, however, the world bank defined corruption as violating laws, by laws and not committed or adhered to them, or exploiting their absence for attaining political, economic and social benefits in favor of a particular group, providing the existence of personal interests for someone (Abbas, 2008). On the other hand, international transparency organization defined corruption as misuse of public position to gain or attain particular interest (Al-Jabiry, 2005), while international monetary fund (IMF), defined corruption as dependent long hands (arms) relationship directed to gaining benefits or interests from this behavior either for one person or a group with interpersonal relationship (Mansour, 2011). Moreover, from a legal perspective, corruption indicate a specialized public employee violating or breaking his duties boundaries and breaking valid laws and by -laws, in an attempt to realize illegal interest either for himself or for others like taking over public funds or private properties or possessions in the country including lands, real estates, or Machineries (Mahdi).

\section{Data Analysis and Hypothesis Testing}

The following criteria will be used to judge response mean intensity:

1) Less than 2.5 low agreement degree.

2) 2.5 to less than 3.5 moderate agreement degree.

3) 3.5 or above high agreement degree.

\subsection{Data Analysis}

Analysis of data related to the first hypothesis which states: external accounts auditor contributes to the prevention of economic corruption, in publicly held companies in Jordan.

Table 1.Means and standards deviation related to the first hypotheses

\begin{tabular}{|c|c|c|c|c|c|}
\hline No. & Rank & Item & M & SD & Degree \\
\hline 1 & 1 & External audit function is one of the major functions in preventing corruption. & 4.60 & 0.59 & High \\
\hline 4 & 2 & $\begin{array}{l}\text { Auditor ability in the optimal investment of various capabilities and their best use in the } \\
\text { prevention of corruption. }\end{array}$ & 4.14 & 0.72 & High \\
\hline 5 & 3 & Auditor commitment and adherence to his neutrality. & 4.11 & 1.07 & High \\
\hline 7 & 4 & Accounts auditor honesty and independence & 4.07 & 1.01 & High \\
\hline 6 & 5 & Existence of financial relationship with Management and auditor acceptance of gifts. & 4.05 & 0.35 & High \\
\hline 2 & 6 & Auditor suitable educational qualification. & 3.91 & 1.04 & High \\
\hline 3 & 7 & Auditors ability to minimize the risk of mistakes existence in financial statements. & 3.75 & 1.21 & High \\
\hline 8 & 8 & $\begin{array}{l}\text { Auditor's behavior in specifying his fees, using techniques that affect his independence like } \\
\text { conditioned fees. }\end{array}$ & 3.66 & 1.24 & High \\
\hline
\end{tabular}


Table 1 shows means and standard deviation of items related to external auditor contribution to the prevention of economic corruption in publicly held Jordanian companies, from which we notice that item (1) "External audit function is one of the major functions in preventing corruption", was ranked first with a mean of (4.60), while item (8) "Auditor's behavior in specifying his fees, using techniques that affect his independence like conditioned fees", was ranked last with a mean of (3.66). Analysis of results related to the second research hypotheses "internal auditor in Jordanian publicly held companies performed his assigned role to prevent economic corruption", according to professional tradition and standards to test the correctness of this hypotheses, means and standard deviation for item related to the extent to which internal auditor, in Jordanian publicly held companies, contributes, through his assigned role, in preventing economic corruption, in accordance with professional traditions and standards.

Table 2. Displays the results

\begin{tabular}{|c|c|c|c|c|c|}
\hline No. & Rank & Item & M & SD & Degree \\
\hline 7 & 1 & $\begin{array}{l}\text { Auditor, through following company's activities, discover deficit aspects in } \\
\text { company's internal control system. }\end{array}$ & 4.10 & 0.97 & High \\
\hline 4 & 2 & $\begin{array}{l}\text { Internal auditor has the capability to make his decision free of pressures from or } \\
\text { adherence to those who will be affected by. }\end{array}$ & 4.07 & 0.78 & High \\
\hline 1 & 3 & Internal audit units professional duties are accurately specified. & 3.96 & 0.51 & High \\
\hline 8 & 4 & $\begin{array}{l}\text { Internal auditor classify risks according to their riskiness and priority to prevent } \\
\text { corruption, as much as possible. }\end{array}$ & 3.84 & 1.41 & High \\
\hline 3 & 5 & $\begin{array}{l}\text { Internal audit report are among the most important means, through which top } \\
\text { management can prevent corruption. }\end{array}$ & 3.75 & 1.21 & High \\
\hline 6 & 2 & $\begin{array}{l}\text { Internal auditors possess sufficient knowledge regarding internal audit standards } \\
\text { issued by internal auditors association. }\end{array}$ & 3.55 & 1.12 & High \\
\hline 8 & 6 & $\begin{array}{l}\text { Internal auditor check adherence to managerial policies and commands as well } \\
\text { as other internal requirements }\end{array}$ & 3.05 & 2.3 & Moderate \\
\hline 7 & 5 & $\begin{array}{l}\text { Internal auditor has the ability to show high objectivity level in his job, and } \\
\text { never adhere to his personal interests. }\end{array}$ & 3.2 & 2.05 & \\
\hline
\end{tabular}

Table 2 showed means and standard deviation of item related to external accounts auditor participation to prevention of corruption in publicly held Jordanian companies. From this table we can see that item (7) auditor, through following company's activities, can discover deficit aspects in the internal audit system, with a mean of (4.10), while item (6) "internal auditor check the adherence to managerial commands and policies, as well as to other internal requirement, was ranked last, with a mean of (3.05).

\subsection{Hypothesis Testing}

$\mathbf{H}_{1}$ : External auditor contributes to corruption prevention in Jordanian publicly held companies.

Table 3. Results of T-test for $\mathrm{H}_{1}$

\begin{tabular}{|c|c|c|c|c|c|c|}
\hline Hypothesis & $\mathbf{N}$ & $\mathbf{M}$ & SD & T. value & DF & Sig. \\
\hline $\begin{array}{l}\text { External auditor contributes to the prevention of economic corruption in Jordanian } \\
\text { publicly held companies }\end{array}$ & 35 & 4.03 & 0.72 & 6.4 & 33 & 0.000 \\
\hline
\end{tabular}

The above table showed statistically significant differences between agreement degree mean score on the first hypotheses and standard score (3), suggesting the acceptance of this hypotheses.

$\mathbf{H}_{2}$ : Internal auditor in publicly held Jordanian companies in his assigned role, performance to present corruption according to professional traditions and standard requirements, table (4) showed these results.

Table 4. Results of $\mathrm{T}-$ Test on $\mathrm{H}_{2}$

\begin{tabular}{|c|c|c|c|c|c|c|}
\hline Hypothesis & $\mathbf{N}$ & $\mathbf{M}$ & SD & $\mathbf{T}$ & DF & Sig. \\
\hline $\begin{array}{l}\text { Internal auditor in publicly held Jordanian companies in his assigned role performance } \\
\text { to prevent corruption according to professional traditions and requirements. }\end{array}$ & 35 & 3.69 & 0.87 & 5.9 & 33 & 0.002 \\
\hline
\end{tabular}


The above table showed statistically significant differences between agreement degree mean scores and the standard score (3), suggesting the acceptance of this hypotheses.

$\mathbf{H}_{3}$ :There is a relationship between auditors educational qualification and experiences, from one hand, and corruption prevention, in publicly held companies, from the other. Table (5) showed results of T-test for testing this hypothesis.

Table 5. Results of t-test for testing H3

\begin{tabular}{|c|c|c|c|c|c|c|}
\hline Hypothesis & $\mathbf{N}$ & M & SD & $\mathbf{T}$ & DF & Sig. \\
\hline $\begin{array}{l}\text { There is a relationship between auditors educational qualification and experience and } \\
\text { corruption prevention in publicly held companies in Jordan }\end{array}$ & 35 & 3.684 & 0.89 & 5.68 & 33 & .002 \\
\hline
\end{tabular}

The above table showed statistically significant relationship between auditor's educational qualifications and experience, from one hand, and economic corruption prevention, in publicly held companies in Jordan, from the other, suggesting the acceptance of the third hypothesis.

\section{Results}

1) Results of current study showed substantial contribution of external accounts auditor in preventing economic corruption in Jordanian publicly held companies.

2) Results also showed substantial contribution of internal accounts auditor in his assigned role, to prevent economic corruption, at publicly held companies in Jordan, according to professional traditions and standards requirements.

3) Results also showed strong and statistically significant, positive relationship between auditor's qualifications and experiences, from one part and economic corruption prevention, in publicly held companies in Jordan.

4) The existence of a significant role of auditing process in preventing economic corruption in Jordanian publicly held companies.

5) The existence of a significant role of auditor's qualification and experiences in the prevention of economic corruption in publicly held companies in Jordan.

6) Internal audit units, in publicly held companies in Jordan, adopt performance standards, which have a positive effect on controlling and improving performance, leading ultimately to preventing economic corruption.

7) Internal audit units, in the majority of companies investigated here, enjoy some degree of independence.

8) Managers and workers, at internal audit units agree on the need for expanding internal and it span to include measuring of performance, because this will result in the improvement of performance as well as preventing financial and administrative corruption of publicly held Jordanian companies.

\section{Recommendations}

1) The need for holding training courses for internal auditors, with the gradual adoption at these courses and generalizing them for all publicly held Jordanian companies.

2) The need for specifying professional duties of internal audit administration, accurately, in publicly held Jordanian companies, through written and documented system.

3) The establishment of direct communication line between auditors and top level management to gain support for his independence.

4) The need for providing auditor with required skills and experiences, to make him capable of to identify, monitor, measure and support of surrounding risks management.

5) Internal and it section should prepare auditing plans, based on expected risks degree in specifying priorities of internal and it department activities, in accordance with general goals of the company.

6) Poverty fighting (which is a major reason for corruption), and seeking social justice as much as possible.

7) Civil society organizations have a prominent role in corruption fighting, which was confirmed by world bank strategies, on corruption fighting, given that these organizations represent a pressure factor on government to be more transparent and clear in its procedures, as well as, their role in recording and monitoring of corruption manifestation, as well as the installation of human values, respect of laws, 
protection of poor classes, and public funds.

8) Intensifying training and development program for control personnel and showing than best control practices for corruption fighting, in all its forms, and applying these experiences practically.

\section{References}

Abbas, S., \& Abbass, S. S. (2008). Administrative and financial corruption in Iraq. Manifestations, reasons and remediation methods, institute of management, Arresafah, Iraq.

Abu-Hmoudh, H. (2002). Corruption and its economic and social reflections. Damascus University Journal, $18(1), 451$.

Al-Jabiry, A. (2005). Economic corruption it's types, reason influences, and remediation methods. Third conference, Om Al-Qura University.

Al-Modalal, Y. S. (2007). The role of internal audit and its function in controlling financial and managerial performance: An empirical study of Palestinian publicly held companies listed in Palestinian stock market. Unpublished master thesis in accounting and finance Gaza university. Retrieved fromhttps://iugspace.iugaza.edu.ps/handle/20.500.12358/18285

Al-Munief, M. (2015). Economic dimensions of corruption. Al-WattanNewspaper.

Arena et al. (2006). Internal audit in Italian organizations: A multiple case study. Managerial Auditing Journal, 21(3), 275-292. https://doi.org/10.1108/02686900610653017

Bakri, H. (2005). The role of internal review in activating economic control at business organizations. Scientific Journal of Commerce Faculty, 30.

Mahdi,S. (n. d.). Administrative corruption: Its reasons, influences and major remedy methods. Retrieved from http://www.nazaha.iq/search_web/muhasbe

Mansour, S. (2011). Economic corruption effects on developmental activity.

Oleimat, K. (2015). Corruption reflections on economic development. PhD Thesis, Faculty of Economic Sciences, Commercial Sciences and Management Sciences, department of economic sciences Algeria.

Omar, M. M. (2011). Corruption and its effect on income and poverty distribution: A Comparative study. $\mathrm{PhD}$ thesis, Commerce and business college, Halwanuniversity Egypt.

Royal message to Adnan Badran. (2005). Prime minister of Jordan, concerning the establishment of a committee for the execution of a general strategy to fight corruption, on 26/6/2005.

Sarens, G., \& Ignace, De B. (2006). Contemporary internal auditing practices: New roles and influencing variables. Evidence from extended case studies. International Journal of Accounting, Auditing, and Performance Evaluation, 3(4). https://doi.org/10.1504/IJAAPE.2006.011206

Zygler, J. (2002). New world masters (p. 115). Arabic unity studies centre, Mohammad Zakarga (TR, 2002), Egypt.

\section{Copyrights}

Copyright for this article is retained by the author(s), with first publication rights granted to the journal.

This is an open-access article distributed under the terms and conditions of the Creative Commons Attribution license (http://creativecommons.org/licenses/by/4.0/). 